\title{
PERLINDUNGAN HUKUM TERHADAP KESELAMATAN KERJA PETUGAS KEBERSIHAN KOTA PEKANBARU
}

\author{
Ardiansah, Silm Oktapani \\ Fakultas Hukum, Universitas Lancang Kuning \\ e-mail: ardiansyah2000@yahoo.com
}

\begin{abstract}
Abstrak
Penelitian ini menggunakan jenis penelitian hukum empiris, yaitu penelitian yang mencermati efektivitas hukum di dalam masyarakat. Teknik pengumpulan data dengan cara observasi, kuesioner, wawancara, dan kajian pustaka. Hasil penelitian menyimpulkan bahwa dinas terkait belum secara lengkap memberikan alat keselamatan kerja kepada petugas kebersihan, petugas kebersihan seringkali mencari alasan untuk tidak memakai alat keselamatan kerja, dan instansi terkait belum melakukan fungsi pengawasan terhadap petugas kebersihan. Adapun kendala disebabkan instansi terkait memberikan alat keselamatan kerja tidak sesuai dengan kebutuhan kerja, ketidak patuhan petugas kebersihan terhadap peraturan yang berlaku, tidak adanya sanksi terhadap petugas kebersihan yang tidak memakai alat keselamatan kerja, dan instansi terkait belum melakukan fungsi pengawasan terhadap petugas kebersihan. Upaya yang perlu dilakukan instansi terkait menyediakan secara lengkap alat keselamatan kerja, para mandor mengingatkan bawahannya untuk memakai alat keselamatan kerja, instansi terkait mengawasi petugas kebersihan, mensosialisasikan bahaya tidak memakai alat keselamatan kerja, dan memberikan sanksi terhadap petugas kebersihan yang tidak memakai alat keselamatan.
\end{abstract}

Kata Kunci:

Keselamatan Kerja; Petugas Kebersihan; Kota pekanbaru

\begin{abstract}
This study aims to analyze the constraints and efforts to protect the law against the work safety of Pekanbaru City cleaners. This research uses empirical legal research, namely research that examines the effectiveness of law in society. Data collection techniques by observation, questionnaires, interviews, and literature review. The results of the study concluded that the relevant agencies had not yet fully provided work safety equipment to cleaning staff, cleaning staff often looked for reasons not to use work safety equipment, and the relevant agencies had not performed the supervisory function of the cleaning staff. The constraints are due to the relevant agencies providing work safety equipment that is not in accordance with work
\end{abstract}


needs, cleaning staff's non-compliance with applicable regulations, there are no sanctions against cleaning workers who do not use work safety equipment, and related agencies have not performed supervisory functions against cleaning officers. Efforts that need to be done by related agencies provide complete safety equipment, the foremen remind their subordinates to use work safety equipment, the relevant agencies supervise cleaning workers, socialize the dangers of not using work safety equipment, and impose sanctions on cleaning workers who do not use safety equipment.

\section{Keywords:}

Work safety; cleaning worke; Pekanbaru city

\section{A. PENDAHULUAN}

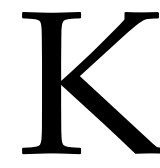

emajuan kota ditandai dengan kebersihan, kota yang bersih dan indah menunjukkan bukti keseriusan pemerintah menjaga kebersihan kota. ${ }^{1}$ Namun, kota seringkali dihadapkan pada berbagai masalah sampah dan sering diperbincangkan oleh masyarakat kota. ${ }^{2}$ Memang sampah selalu menjadi masalah bagi kota-kota besar di Indonesia, tidak terkecuali Kota Pekanbaru. ${ }^{3}$

Untuk mengantisipasi masalah sampah, petugas kebersihan bertanggung jawab atas pelaksanaan pengelolaan sampah. Petugas kebersihan atau lazim dikenal sebagai pasukan kuning adalah sebutan bagi kumpulan profesi yang bekerja membersihkan sampah kota. ${ }^{4}$ Petugas kebersihan yang memakai seragam berwarna kuning dilengkapi alat kerja, seperti sapu lidi, sekop, pemotong rumput, dan karung sampah. Semua alat kerja tersebut menjadi bagian yang tidak terpisahkan dari tempat kerja..$^{5}$

Petugas kebersihan tidak lepas dari masalah keselamatan kerja. Petugas kebersihan rentan terkena penyakit ketimbang pekerja struktural. ${ }^{6}$ Petugas kebersihan yang bekerja membersihkan kota lebih banyak bergerak, terkena sinar matahari, dan mempunyai risiko yang tinggi berupa ancaman kecelakaan kerja. Kecelakaan kerja adalah suatu peristiwa yang tidak dikehendaki, merusak harta

\footnotetext{
${ }^{1}$ Gea Sundariana,Pengawasan Petugas Operasional Kebersihan Kota Pekanbaru (Studi Kasus KeselamatanTenaga Kerja di Kecamatan Tampan), Jom FISIP Universitas Riau, Vol. 2, No. 2, 2015, h. 2.

${ }^{2}$ Masnidar dan Mahyuzar,Strategi Komunikasi Dinas Lingkungan Hidup, Kebersihan Dan Keindahan Kota Banda Aceh Dalam Menyebarkan Informasi Penanggulangan Sampah Pada Masyarakat Kota Banda, Jurnal ilmiah mahasiswa FISIP Unsyiah, Vol. 3, No. 3, 2016, h. 2.

${ }^{3}$ Monice dan Perinov, Analisis Potensi Sampah Sebagai Bahan Baku Pembangkit Listrik Tenaga Sampah (PLTS) Di Pekanbaru, Jurnal SainETIn Universitas LancangKuning, Vol. 1, No. 1, 2016, h.10.

4 Dwi Maharani, Manajemen Komunikasi pada Petugas Kebersihan Kota Palembang, Jurnal Komunikasi, Vol 11, No. 1, Juni 2018, h. 119-128.

${ }^{5}$ Rahma Dwi Putri dan Harry Theozard Fikri, Hubungan Antara Lingkungan Kerja Fisik Dengan Kesehatan dan Keselamatan Kerja pada Pasukan Kuning dii Kota Padang, Jurnal PSYCHE 165, Vol. 12, No. 2, 2019, h. 184.

${ }^{6}$ Norsita Agustina, Dkk,Hubungan Karakteristik Petugas Kebersihan Dengan Pengelolaan Sampah Di Puskesmas Kota Banjar Baru, Jurnal Publikasi Kesehatan Masyarakat Indonesia, Vol. 4, No. 2, 2017, h. 63.
} 
benda, dan sebagainya. ${ }^{7}$ Kecelakaan kerja yang sering terjadi disebabkan penggunaan alat pemotong rumput dan penanganan alat berat. ${ }^{8}$ Oleh karena itu, perlu alat keselamatan kerja agar petugas kebersihan senantiasa sehat, nyaman, dan selamat. ${ }^{9}$ Walaupun menghadapi masalah keselamatan kerja, petugas kebersihan terus semangat bekerja demi memenuhi kebutuhan keluarganya. ${ }^{10}$

Signifikansi keselamatan kerja telah ditunjukkan oleh Pemerintah Kota Pekanbaru dengan memberlakukan Peraturan Daerah Kota Pekanbaru Nomor 8 Tahun 2014 tentang Pengelolaan Sampah. Pasal 42 ayat (1) menyatakan bahwa Setiap petugas kebersihan harus mendapatkan perlindungan dari penyelenggara pengelolaan sampah. Seterusnya, ayat (2) menyatakan Perlindungan petugas kebersihan sebagaimana dimaksud pada ayat (1) berupa perlindungan keselamatan kerja sesuai dengan standar keselamatan dan kesehatan kerja. Selanjutnya, ayat (3) menyatakan Perlindungan keselamatan petugas kebersihan berupa alat pelindung diri untuk melindungi seluruh atau sebagian tubuhnya dari kemungkinan adanya pemaparan potensi bahaya, kecelakaan dan penyakit pada saat melakukan tugas. Kemudian ayat (4) menyatakan Alat pelindung diri sebagaimana dimaksud pada ayat (3) disesuaikan dengan kebutuhan yang meliputi antara lain: alat pelindung kepala, alat pelindung mata, alat pelindung pernafasan atau masker, alat pelindung tangan, baju pelindung; dan alat pelindung kaki. Pemberlakuan Peraturan Daerah tersebut bertujuan agar petugas kebersihan mendapatkan perlindungan keselamatan kerja. Apabila tinggi kesadaran petugas kebersihan memakai alat pelindung diri, maka akan sangat berpengaruh pada tingkat keselamatan kerja, sebaliknya apabila rendah kesadaran petugas kebersihan untuk memakai alat pelindung diri, maka semakin besar kesempatan terjadinya kecelakaan kerja. ${ }^{11}$

Saat ini petugas kebersihan Kota Pekanbaru sebanyak 900 orang, petugas kebersihan tersebut meliputi petugas penyapu jalan dan petugas pengangkut sampah. ${ }^{12}$ Dinas Kebersihan dan Pertamanan Kota Pekanbaru masih mengalami beberapa masalah mengenai keselamatan kerja terhadap petugas kebersihan, antara lain: sering terjadi kecelakaan lalu lintas disebabkan petugas kebersihan tidak membawa peralatan kerja yang diletakkan di pinggir jalan, pengguna jalan tidak

${ }^{7}$ Dody Saputra, Analisis Hubungan Keselamatan dan Kesehatan Kerja (K3) Terhadap Kepuasan Kerja Karyawan Di PT Dystar Colours Indonesia, Skripsi, Program Sarjana Fakultas Ekonomi Dan Manajemen Institut Pertanian Bogor, 2012.

${ }^{8}$ Syarifah Yeti Fakhrina \& Asniar, Keselamatan dan Kesehatan Kerja Pada Petugas Kebersihan Di Kota Banda Aceh, Jurnal Program Studi Ilmu Keperawatan Universitas Syiah Kuala Banda Aceh, 2017, h. 2.

${ }^{9}$ Irzal,Dasar-dasar Kesehatan dan Keselamatan Kerja, (Jakarta: Kencana, 2016), h. 13.

${ }^{10}$ Rahma Dwi Putri dan Harry Theozard Fikri, Loc. Cit.

${ }^{11}$ Edwina Rudyarti, Hubungan Pengetahuan Keselamatandan Kesehatankerjadan Sikappenggunaan Alat Pelindung Diridengan Kejadian Kecelakaan Kerjapada Pengrajin Pisau Batik Di PT.X, Prosiding Seminar Nasional Hasil-Hasil Penelitian Dan Pengabdian Bidang K3, 2017, h. 12.

${ }^{12}$ https://pekanbaru.tribunnews.com/2018/06/14/sekitar-900-petugas-kebersihan-siap-jaga-pekanbarudari-sampah-saat-lebaran https://pekanbaru.tribunnews.com, diakses tanggal 5 Agustus 2019, pukul 06 WIB. 
melihat petugas kebersihan disebabkan tidak memakai pakaian yang menyolok, rompi, dan helm kerja, dan lain-lain. ${ }^{13}$

Berdasarkan hasil pengamatan peneliti banyak petugas kebersihan yang tidak memakai alat keselamatan kerja pada saat membersihkan sampah di Jalan Sudirman, jalan HR Soebrantas, Jalan SM Amin, Jalan Arifin Ahmad, dan beberapa jalan lainnya. Petugas kebersihan bekerja tidak memakai alat keselamatan kerja, seperti penutup kepala, tidak memakai rompi, dan seragam kerja.Petugas kebersihan tetap saja bekerja membersihkan kota tanpa alat keselamatan kerja.

Penelitian ini penting dilaksanakan karena banyak petugas kebersihan Kota Pekanbaru yang tidak memakai alat keselamatan kerja saat bekerja membersihkan kota. Penelitian ini bertujuan untuk mengidentifikasi berbagai masalah mengenai perlindungan hukum terhadap keselamatan kerja petugas kebersihan Kota Pekanbaru, menganalisis kendala perlindungan hukum terhadap keselamatan kerja petugas kebersihan Kota Pekanbaru, dan menganalisis upaya perlindungan hukum terhadap keselamatan kerja petugas kebersihan Kota Pekanbaru.

Penelitian ini berupaya menghasilkan solusi mengenai perlindungan hukum terhadap keselamatan kerja petugas kebersihan Kota Pekanbaru. Penelitian ini tentu memiliki dampak nyata karena memberikan solusi mengenai perlindungan hukum terhadap keselamatan kerja petugas kebersihan di Kota Pekanbaru. Dengan dilaksanakannya penelitian ini diharapkan agar bisa menyelesaikan permasalahan kesehatan dan keselamatan kerja petugas kebersihan Kota Pekanbaru.

\section{B. METODE PENELITIAN}

Penelitian ini menggunakan jenis penelitian hukum empiris, penelitian hukum empiris bertujuan untuk mencermati efektivitas hukum di dalam masyarakat. Penelitian hukum empiris merupakan kajian yang mengungkapkan fakta apa adanya. Penelitian ini akan mengidentifikasi berbagai masalah petugas kebersihan tidak memakai alat keselamatan kerja dan menganalisis solusi untuk mengatasi masalah agar terwujud perlindungan hukum terhadap keselamatan kerja petugas kebersihan sampah di Kota Pekanbaru.

Teknik pengumpulan data dalam penelitian ini berdasarkan observasi, kuisioner, wawancara, dan kajian pustaka. Perbedaan teknik pengumpulan data ini disebabkan perbedaan responden dalam penelitian ini. Penelitian ini menggunakan metode analisa data kualitatif, yaitu suatu cara analisis yang menghasilkan data deskriptif analitis, yaitu apa yang dipaparkan oleh responden secara lisan atau tulisan, perilaku obyek yang diteliti, dan dipelajari secara utuh. ${ }^{14}$

Penentuan Kota Pekanbaru sebagai lokasi dalam penelitian ini didasari dua pertimbangan. Pertama, Kota Pekanbaru adalah Ibu Kota Provinsi Riau. Kedua, Kota Pekanbaru yang berkembang menjadi kota metropolitan sering menghadapi masalah

\footnotetext{
${ }^{13}$ GeaSundariana, Pengawasan Petugas Operasional Kebersihan Kota Pekanbar, h. 5.

${ }^{14}$ Soerjono Soekanto, Pengantar Penelitian Hukum, (Jakarta:UI Press, 2008), h. 154.
} 
sistem pengelolaan sampah. Ketiga, masih banyak petugas kebersihan sampah Kota Pekanbaru yang tidak menggunakan alat keselamatan kerja saat bekerja, meskipun Pemerintah Kota Pekanbaru telah memberlakukan Peraturan Daerah Nomor 8 Tahun 2014 tentang Pengelolaan Sampah.

Responden dalam penelitian ini sebagai berikut : Petugas kebersihan sampah Kota Pekanbaru, Kepala Dinas Kebersihan dan Pertamanan Kota Pekanbaru, Kepala Dinas Tenaga Kerja dan Transmigrasi Provinsi Riau, Ketua Komisi IV Dewan Perwakilan Rakyat Daerah Kota Pekanbaru, dan Pengamat Hukum Ketenegakerjaan Kota Pekanbaru.

\section{HASIL DAN PEMBAHASAN}

1. Perlindungan Hukum Terhadap Keselamatan Kerja Petugas Kebersihan Kota Pekanbaru

Kota Pekanbaru yang terletak di Pulau Sumatera adalah Ibu Kota Provinsi Riau. Kota Pekanbaru terus berkembang pesat sebagai Kota Metropolitan. Kota Pekanbaru merupakan kota yang mendapat julukan Kota Madani. Kota Pekanbaru mempunyai luas wilayah sekitar $632,3 \mathrm{~km}^{2}$. Kota Pekanbaru mempunyai 12 Kecamatan dan 83 Kelurahan. Total penduduk Kota Pekanbaru berjumlah 1.046.566 jiwa. ${ }^{15}$ Kota Pekanbaru telah berkali-kali memenangkan Piala Adipura dari Pemerintah Pusat. Penghargaan diberikan karena Pemerintah Kota Pekanbaru berhasil menata dan kebersihan kota. Untuk mewujudkan kebersihan kota, maka petugas kebersihan setiap hari membersihkan Kota Pekanbaru agar kelihatan bersih dan indah. ${ }^{16}$ Namun, lazimnya kota selalu menghadapi masalah sampah termasuk Kota Pekanbaru. Diperkirakan jumlah timbunan sampah Kota Pekanbaru sekitar 523 ton perharinya. ${ }^{17}$

Pemerintah Kota Pekanbaru telah memberlakukan Peraturan Daerah Kota Pekanbaru Nomor 08 Tahun 2014 tentang Pengelolaan Sampah. Aturan ini menyebabkan Pemerintah Kota Pekanbaru bertindak sebagai pengelola urusan sampah, mulai dari petugas penyapu jalan, penyediaan tempat sampah, pengangkutan sampah, tempat pembuangan akhir sampah, hinggga petugas kebersihan sampah. Pemberlakuan Peraturan Daerah tersebut, ternyata belum sejalan dengan praktik di lapangan. Berdasarkan observasi penulis, masih banyak petugas kebersihan yang bekerja tidak memakai alat keselamatan kerja, seperti di jalan Jenderal Sudirman, Jalan Riau, Jalan HR Sobrantas, Jalan SM Amin, Jalan Arifin Ahmad, Jalan Kaharuddin Nasution, Jalan Riau, Jalan KH. Ahmad Dahlan, Jalan Diponegoro, Jalan Jenderal Ahmad Yani, dan beberapa jalan lainnya. Petugas kebersihan bekerja memakai alat keselamatan kerja seadanya sehingga berpotensi menimbulkan penyakit .

\footnotetext{
${ }^{15}$ Data BPS Kota Pekanbaru 2018.

${ }^{16}$ Gea Sundariana, Pengawasan Petugas Operasional Kebersihan Kota Pekanbaru, h. 2.

${ }^{17}$ Gea Sundariana, Pengawasan Petugas Operasional Kebersihan Kota Pekanbaru, h. 2.
} 
Selain hasil observasi tersebut, peneliti telah menyerahkan kuesioner terhadap petugas kebersihan mengenai perlindungan hukum terhadap keselamatan kerja petugas kebersihan Kota Pekanbaru. Berdasarkan hasil pengisian kuisioner 40 orang petugas kebersihan yang bertindak sebagai responden diperoleh data sebanyak $87 \%$ responden mengatakan bahwa petugas kebersihan belum mengetahui adanya Peraturan Daerah Kota Pekanbaru Nomor 8 Tahun 2014 tentang Pengelolaan Sampah yang mengatur perihal petugas kebersihan harus mendapat perlindungan dari penyelenggara pengelolaan sampah. Perlindungan keselamatan kerja sesuai standar kesehatan dan keselamatan kerja.

Pada bagian lain, sebanyak 97\% responden menyatakan Dinas Kebersihan dan Pertamanan telah memberikan alat keselamatan kerja, akan tetapi alat keselamatan kerja yang diberikan kurang lengkap. Petugas kebersihan sampah diberikan sepatu boot dan baju sekali saja. Peralatan ini diberikan pada awal kerja dan tidak pernah diadakan penggantian, padahal sepatu boot dan baju sudah tidak layak pakai. Petugas kebersihan kerap kali tidak memakai alat keselamatan kerja disebabkan ada sebagian petugas kebersihan tidak mendapatkan alat keselamatan kerja dan ada pula sebagian petugas kebersihan yang mendapat alat keselamatan kerja secara tidak lengkap.

Selain data dari petugas kebersihan, peneliti juga telah mewancarai beberapa responden mengenai perlindungan hokum terhadap keselamatan kerja petugas kebersihan Kota Pekanbaru. Kepala Dinas Kebersihan dan Pertamanan Kota Pekanbaru mengemukakan telah memberikan alat perlengkapan keselamatan kerja sesuai kebutuhan kerja, seperti sepatu boot, sarung tangan, rompi, dan jas hujan, kecuali helm keselamatan. Kepala Dinas Kebersihan dan Pertamanan telah mengingatkan petugas kebersihan agar memakai alat keselamatan kerja apalagi saat menyapu jalan, memungut sampah, dan mengangkut sampah ke tempat tujuan. Menurut Kepala Dinas Kebersihan dan Pertamanan, pekerja memungut sampah berbeda dengan pekerja bangunan. Pekerja memungut sampah perlu memakai alat perlengakapan kerja untuk melindungi dirinya dari bahaya kesehatan dan keselamatan kerja. ${ }^{18}$

Menurut Kepala Dinas Tenaga Kerja dan Transmigrasi Provinsi Riau, pelaksanaan Peraturan Daerah Kota Pekanbaru Nomor 8 Tahun 2014 tentang Pengelolaan Sampah menjadi tugas dan pengawasan Satuan Polisi Pamong Praja. Alasannya Satuan Polisi Pamong Praja adalah pelaksana Peraturan Daerah. Dinas Kebersihan dan Pertamanan harus bertindak langsung di lapangan mengingatkan petugas kerbersihan agar memakai alat keselamatan kerja. Adapun Dinas Tenaga Kerja dan Transmigrasi Provinsi Riau bertindak hanya sebagai pengawal dalam pelaksanaan Peraturan Daerah tersebut. Dinas Kebersihan dan Pertamanan

18 Wawancara denganKepala Dinas Kebersihan dan Pertamanan Kota Pekanbaru yang diwakili oleh Nofan Serwanto selaku Kepala Bagian Perlengkapan, tanggal 17 Juni 2019, pukul 10.00 WIB, di Kantor Dinas Kebersihan dan Pertamanan Kota Pekanbaru. 
memberikan alat keselamatan kerja. Sementara petugas kebersihan harus memakai alat keselamatan kerja. Apabila petugas kebesihan tidak memakai alat keselamatan kerja, maka hal ini disebabkan rendahnya pemahaman dan kurangnya kesadaran petugas kebersihan mengenai pentingnya alat keselamatan kerja. ${ }^{19}$

Ketua Komisi IV DPRD Kota Pekanbaru sangat mendukung pemberlakuan Peraturan Daerah Kota Pekanbaru Nomor 8 Tahun 2014 tentang Pengelolaan Sampah. Dinas Kebersihan dan Pertamanan dan Petugas kebersihan sampah wajib mematuhi Peraturan Daerah tersebut. Dalam pengamatannya, petugas kebersihan masih belum memakai alat keselamatan kerja saat bekerja membersihkan kota disebabkan alasan risih memakai rompi, kaki terasa panas memakai sepatu boot, kerja lebih mudah tanpa sarung tangan, dan sebagainya. ${ }^{20}$

Pengamat Hukum Ketenagakerjaan Kota Pekanbaru berpendapat bahwa Peraturan Daerah Kota Pekanbaru Nomor 8 Tahun 2014 tentang Pengelolaan Sampah dibuat untuk melindungi petugas kebersihan. Adanya Peraturan Daerah tersebut menjadi kepastian untuk memenuhi standar bagi perlindungan pekerja. Dalam pengamatannya, hanya sebagian petugas kebersihan yang memakai alat keselamatan kerja. Sedangkan sebagian yang lain tidak memakai alat keselamatan kerja. Sesungguhnya, pemakaian alat keselamatan kerja bukan sekedar untuk menunaikan kewajiban, akan tetapi untuk melindungi petugas kebersihan dari ancaman bahaya kesehatan dan keselamatan. ${ }^{21}$

Mencermati data dari petugas kebersihan dan Dinas Kebersihan dan Pertamanan tersebut jelas sekali perlindungan hukum terhadap keselamatan kerja petugas kebersihan Kota Pekanbaru belum terlaksana sebagaimana diatur dalam Peraturan Daerah Kota Pekanbaru Nomor 8 Tahun 2014 tentang Pengelolaan Sampah. Tugas dan tanggungjawab Dinas Kebersihan dan Pertamanan memberikan alat keselamatan kerja kepada petugas kebersihan, seperti alat pelindung kepala, alat pelindung mata, alat pelindung pernafasan atau masker, alat pelindung tangan, baju pelindung, dan alat pelindung kaki.

Mencermati perilaku petugas kebersihan Kota Pekanbaru yang tidak memakai alat keselamatan kerja sebagai sikap ketidak patuhan terhadap perintah Dinas Kebersihan dan Pertamanan. Perilaku petugas kebersihan tersebut jelas tidak sejalan dengan Peraturan Daerah Kota Pekanbaru Nomor 8 Tahun 2014 tentang Pengelolaan Sampah karena bisa membahayakan kesehatan dan keselamatan dirinya.

\section{Kendala Perlindungan Hukum Terhadap Keselamatan Kerja Petugas Kebersihan Sampah Kota Pekanbaru}

${ }^{19}$ Wawancara denganKepalaDinas Tenaga Kerja dan Transmigrasi Provinsi Riau yang diwakili oleh Ahmad Zikri,selaku Kepala Bidang Kesehatan dan Keselamatan Kerja, tanggal 25 Juli 2019, pada pukul 14.00 WIB di Dinas Tenaga Kerja dan Transmigrasi Provinsi Riau.

${ }^{20}$ Wawancara dengan Roni Amriel, S.H., M.H., selaku Ketua Komisi IV DPRD Kota Pekanbaru pada tanggal 29 Juli 2019, pukul 10.00 WIB, di Gedung DPRD Kota Pekanbaru.

${ }^{21}$ Wawancara dengan Dr. Dessy Artina, S.H., M.H., selaku Pengamat Hukum Ketenagakerjaan Kota Pekanbaru,tanggal 8 Agustus 2019, pukul 14.00 WIB di Universitas Riau. 
Beragam kendala perlindungan hukum terhadap keselamatan kerja petugas kebersihan Kota Pekanbaru. Sebanyak 60\% responden petugas kebersihan mengatakan bahwa Dinas Kebersihan dan Pertamanan tidak mewajibkan petugas kebersihan untuk memakai alat keselamatan kerja. Sementara itu, sebanyak 40\% responden petugas kebersihan mengatakan Dinas Kebersihan dan Pertamanan pernah mewajibkan petugas kebersihan untuk memakai alat keselamatan kerja. Dinas Kebersihan dan Pertamanan telah memberikan alat keselamatan kerja hanya pada awal masuk kerja, akan tetapi tidak lengkap alat keselamatan kerjanya. Dari perbedaan pendapat tersebut menunjukkan masih kurang kuat komitmen Dinas Kebersihan dan Pertamanan untuk memberikan perlindungan hukum terhadap keselamatan kerja petugas kebersihan Kota Pekanbaru.

Kepala Dinas Kebersihan dan Pertamanan menjelaskan kendala perlindungan hukum terhadap keselamatan kerja petugas kebersihan Kota Pekanbaru dari segi anggaran dana pengadaan alat keselamatan kerja yang minim dan ketidakpatuhan petugas kebersihan terhadap peraturan yang berlaku. Menurut Kepala Dinas Kebersihan dan Pertamanan, anggaran dana pengadaan alat keselamatan kerja perlu dianggarkan setahun sekali meski jumlah dananya tidak memadai untuk pembelian sepatu dan sarung tangan. Sementara itu, ketidakpatuhan petugas kebersihan disebabkan tidak ada sanksi terhadap petugas kebersihan yang tidak memakai alat keselamatan kerja. Petugas kebersihan tidak memakai alat keselamatan kerja karena dua alasan. Pertama, apabila memakai sarung tangan terasa kurang nyaman dan susah mengangkut sampahnya. Kedua, sepatu boot yang dipakai petugas kebersihan mengandung banyak zat asam dari sampah sehingga kaki kepanasan. ${ }^{22}$ Penjelasan ini memperlihatkan Dinas Kebersihan dan Pertamanan permisif menghadapi kendala perlindungan hukum terhadap keselamatan kerja petugas kebersihan.

Kepala Dinas Tenaga Kerja dan Transmigrasi Provinsi Riau mengungkapkan kendala perlindungan hukum terhadap keselamatan kerja petugas kebersihan Kota Pekanbaru disebabkan alasan alat perlengkapan yang diberikan tidak sesuai dengan kebutuhan kerja dan alasan petugas kebersihan tidak mau memakai alat keselamatan kerja dengan mencari berbagai alasan. Kepala Dinas Tenaga Kerja dan Transmigrasi menyesalkan perilaku petugas kebersihan yang tidak memakai alat keselamatan kerja karena pemakaian alat keselamatan kerja bertujuan untuk melindungi petugas kebersihan dari bahaya kesehatan dan keselamatan kerja. ${ }^{23}$ Ungkapan tersebut menunjukkan adanya kendala pada alat keselamatan kerja dan kendala pada perilaku petugas kebersihan yang tidak peduli dengan keselamatan dirinya.

${ }^{22}$ Wawancara denganKepala Dinas Kebersihan dan Pertamanan Kota Pekanbaru yang diwakili oleh Nofan Serwanto selaku Kepala Bagian Perlengkapan, tanggal 17 Juni 2019, pukul 10.00 WIB, di Kantor Dinas Kebersihan dan Pertamanan Kota Pekanbaru.

${ }^{23}$ Wawancara dengan Kepala Dinas Tenaga Kerja dan Transmigrasi Provinsi Riau yang diwakili oleh Ahmad Zikri,selaku Kepala Bidang Kesehatan dan Keselamatan Kerja, tanggal 25 Juli 2019, pukul 14.00 WIB, di Dinas Tenaga Kerja dan Transmigrasi Provinsi Riau. 
Kendala perlindungan hukum terhadap keselamatan kerja petugas kebersihan Kota Pekanbaru juga dicermati oleh wakil rakyat. Ketua Komisi IV DPRD Kota Pekanbaru mengemukakan kendala disebabkan perubahan pengelola kebersihan. Pada waktu pengelolaan sampah dilaksanakan oleh Dinas Kebersihan dan Pertamanan, petugas kebersihan dengan tertib dan terkendali memakai alat keselamatan kerja. Namun, setelah adanya perubahan pengelola kebersihan sampah dari pemerintah kepada pihak swasta, maka berubah pula perilaku petugas kebersihan. Petugas kebersihan tidaklagi memakai alat keselamatan kerja. Perilaku petugas kebersihan ini bisa disebabkan pihak swasta kurang peduli mengenai keselamatan kerja petugas kebersihan dan kurang pengawasan instansi terkait mengenai keselamatan kerja petugas kebersihan. ${ }^{24}$ Pernyataan Ketua Komisi IV DPRD tersebut hanya menyinggung perilaku petugas kebersihan, namun tidak disinggung kendala kewajiban instansi terkait memberikan alat keselamatan kerja kepada petugas kebersihan.

Senada dengan wakil rakyat tersebut, pengamat Hukum Ketenaga kerjaan Kota Pekanbaru mengamati masih adanya petugas kebersihan yang tidak memakai alat keselamatan kerja disebabkan belum berjalannya fungsi pengawasan yang dilakukan oleh instansi terkait. Agar petugas kebersihan terus memakai alat keselamatan kerja, maka Dinas Kebersihan dan Pertamanan Kota Pekanbaru harus rutin melakukan pengawasan terhadap petugas kebersihan saat membersihkan kota. Dengan adanya pengawasan, maka petugas kebersihanakan senantiasa memakai alat keselamatan kerja sehingga melindungi dirinya dari bahaya kesehatan dan keselamatan. ${ }^{25}$

Berbagai alasan mengenai kendala perlindungan hukum terhadap keselamatan kerja petugas kebersihan. Yane Liswanti, Dkk dalam penelitiannya menyimpulkan kendala disebabkan rendahnya tingkat kepatuhan petugas kebersihan untuk memakai alat pelindung diri sebagai alat keselamatan kerja lazimnya mengarah kepada sistem manajemen keselamatan yang gagal, kurangnya stimulan dari pimpinan, terbatasnya sarana, dan kurangnya kesadaran petugas kebersihan terhadap keselamatan kerja. ${ }^{26}$

Bagaimanapun, petugas kebersihan harus melindungi dirinya dengan memakai alat pelindung diri atau alat keselamatan kerja. Perilaku petugas kebersihan yang tidak memakai alat keselamatan kerja bisa mengakibatkan penularan penyakit kulit karena setiap hari bersentuhan langsung dengan sampah. Oleh karena itu, petugas kebersihan harus memakai alat pelindung diri agar dapat meminimalkan risiko

${ }^{24}$ Wawancara dengan Roni Amriel, S.H., M.H selaku Ketua Komisi IV DPRD Kota Pekanbaru tanggal 29 Juli 2019, pukul 10.00 WIB, di Gedung DPRD Kota Pekanbaru.

${ }^{25}$ Wawancara dengan Dr. Dessy Artina, S.H., M.H selaku pengamat hukum ketenagakerjaan Kota Pekanbaru,tanggal 8 Agustus 2019, pada pukul 14.00 WIB, di Universitas Riau.

${ }^{26}$ Yane Liswanti, Ardini S Raksanagara, Sri Yunita,Faktor-faktor Yang Berhubungan Dengan Kepatuhan Penggunaan Alat Pelindung Diri (ADP) Serta Kaitannya Terhadap Status Kesehatan Pada Petugas Pengumpul Sampah Rumah Tangga Di Kota Tasikmalaya Tahun 2014, Jurnal Kesehatan Bakti Tunas Husada, Vol. 13, No.1, 2015, h. 197. 
penularan penyakit kulit. ${ }^{27}$ Sebab alat perlindungan diri berfungsi untuk melindungi sebagian atau seluruh tubuh dari potensi bahaya di tempat kerja. Apabila dikaji secara kritis, sesungguhnya keselamatan kerja mempunyai beberapa tujuan. Pertama, agar setiap pekerja memperoleh keselamatan dan kesehatan kerja secara fisik, sosial, dan psikologis. Kedua, agar perlengkapan kerja digunakan dengan sebaik-baiknya. Ketiga, agar semua hasil produksi dipelihara keamanannya. Keempat, agar adanya peningkatan kesehatan gizi pegawai. Kelima, agar adanya peningkatan gairah kerja. Keenam, agar terhindar dari gangguan kesehatan. Ketujuh, agar setiap pekerja merasa terlindungi. ${ }^{28}$

\section{Upaya Perlindungan Hukum Terhadap Keselamatan Kerja Petugas Kebersihan Sampah Kota Pekanbaru}

Beragam pendapat mengenai upaya perlindungan hukum terhadap keselamatan kerja petugas kebersihan Kota Pekanbaru. Sebanyak 100\% responden mengatakan pemerintah harus memperhatikan petugas kebersihan dalam melaksanakan pekerjaannya sehari-hari. Alat keselamatan kerja yang diberikan kepada petugas kebersihan harus sesuai dengan prosedur dan peraturan yang berlaku. Petugas kebersihan menyadari pentingnya memakai alat keselamatan kerja. Oleh karena itu, perlu perhatikan khusus dari Dinas Kebersihan dan Pertamanan untuk memastikan ketersediaan alat keselamatan kerja bagi petugas kebersihan.

Kepala Dinas Kebersihan dan Pertamanan Pemerintah Kota Pekanbaru bahwa upaya perlindungan hukum terhadap keselamatan kerja petugas kebersihan adalah dengan cara mengumpulkan para mandor petugas kebersihan, kemudian memberikan arahan kepada petugas kebersihan yang menjadi bawahannya untuk memakai alat keselamatan kerja. Dinas Kebersihan dan Pertamanan terus berupaya mengingatkan para mandor agar memberitahu petugas kebersihan untuk memakai alat keselamatan kerja. Tujuannya agar terhindar dari bahaya kesehatan dan keselamatan kerja. ${ }^{29}$ Upaya yang disampaikan Kepala Dinas Kebersihan dan Pertamanan meletakkan peran mandor lebih penting ketersediaan alat keselamatan kerja. Pendapat tersebut kurang tepat. Ketidakpatuhan petugas kebersihan lebih disebabkan dinas terkait tidak memberikan alat keselamatan kerja secara komplit sesuai standard keselamatan dan kesehatan kerja.

Kepala Dinas Tenaga Kerja dan Transmigrasi Provinsi Riau lebih tegas berpendapat mengenai upaya perlindungan hukum terhadap keselamatan kerja petugas kebersihan. Menurut Kepala Dinas Tenaga Kerja dan Transmigrasi, petugas

27 Ni Putu Rusmini, Perilaku Penggunaan Alat Pelindung Diri dan Penularan Penyakit Kulit Pada Petugas TPS di Kecamatan Sawahan, Adi Husada Nursing Journal, Vol. 1, No. 2, Desember 2015, h. 40.

28 Hariza Adnani, Perilaku Petugas Pengumpul Sampah Untuk Melindungi Dirinya Dari Penyakit Bawaan Sampah di Wilayah Patang Puluhan Yogyakarta Tahun 2009, Jurnal KESMAS, Vol. 4, No. 3, 2010 , h. 145.

${ }^{29}$ Wawancara denganKepala Dinas Kebersihan dan Pertamanan Kota Pekanbaru yang diwakili oleh Nofan Serwanto selaku Kepala Bagian Perlengkapan, tanggal 17 Juni 2019, pukul 10.00 WIB, di Kantor Dinas Kebersihan dan Pertamanan Kota Pekanbaru. 
kebersihan harus memakai alat keselamatan kerja. Apabila tidak memakai alat keselamatan kerja, maka petugas kebersihan harus diberi peringatan, teguran, dan sanksi berupa surat peringatan pertama, surat peringatan kedua, dan surat peringatan ketiga. Peringatan, teguran, dan sanksi perlu dilakukan agar petugas kebersihan senantiasa memakai alat keselamatan kerja saat bekerja membersihkan sampah. Semua pihak yang terkait dalam pengelolaan sampah baik Kepala Dinas, Koordinator, maupun Pengawas Lapangan harus mengawasi petugas kebersihan agar memakai senantiasa alat keselamatan saat bekerja membersihkan sampah. ${ }^{30}$

Senada dengan pendapat Kepala Dinas Tenaga Kerja dan Transmigrasi Provinsi Riau tersebut, Ketua Komisi IV DPRD Kota Pekanbaru berpendapat upaya perlindungan hukum terhadap keselamatan kerja petugas kebersihan adalah meningkatkan pengawasan terhadap petugas kebersihan. Kenyataan masih banyak petugas kebersihan yang tidak memakai alat keselamatan kerja disebabkan kurangnya pengawasan instansi terkait terhadap petugas kebersihan sampah. Dinas Kebersihan dan Pertamanan perlu terus mengawasi petugas kebersihan agar memakai alat keselamatan kerja agar terhindar dari bahaya kesehatan dan keselamatan kerja. ${ }^{31}$

Menurut Pengamat Hukum Ketenagakerjaan, upaya perlindungan hukum terhadap keselamatan kerja petugas kebersihan dengan cara Dinas Kebersihan dan Pertamanan melakukan pengawasan terhadap petugas kebersihan agar memakai alat keselamatan kerja sesuai dengan standar keselamatan kerja. Fungsi pengawasan Dinas Kebersihan dan Pertamanan harus dilaksanakan terhadap petugas kebersihan. Apabila fungsi pengawasan dilaksanakan, maka petugas kebersihan akan terus diperhatikan dan diawasi pemakaian alat keselamatan kerja saat bekerja membersihkan sampah. ${ }^{32}$

Mencermati berbagai upaya tersebut, Herbasuki menyimpulkan bahwa pengawasan merupakan suatu aktivitas untuk memperoleh kepastian apakah aktivitas sudah dilakukan sesuai rencana atau tidak. Pada prinsipnya pengawasan merupakan kegiatan membandingkan keadaan yang seharusnya dengan keadaan yang sebenarnya terjadi. ${ }^{33}$ Demikian pula Syariah Yeti Fakhrina dan Asniar dalam penelitiannya menyimpulkan bahwa pengawasan sangat penting dilakukan terhadap petugas kebersihan. Dinas terkait harus memberikan pengawasan yang

${ }^{30}$ Wawancara dengan Kepala Dinas Tenaga Kerja dan Transmigrasi Provinsi Riau yang diwakili oleh Ahmad Zikri,selaku Kepala Bidang Kesehatan dan Keselamatan Kerja, tanggal 25 Juli 2019, pada pukul 14.00 WIB, di kantor Dinas Tenaga Kerja dan Transmigrasi Provinsi Riau.

${ }^{31}$ Wawancara dengan Roni Amriel, S.H., M.H selaku Ketua Komisi IV DPRD Kota Pekanbaru, tanggal 29 Juli 2019, pukul 10.00 WIB, di Gedung DPRD Kota Pekanbaru.

${ }^{32}$ Wawancara dengan Dr. Dessy Artina, S.H., M.H selaku Pengamat Hukum Ketenagakerjaan Kota Pekanbaru, tanggal 8 Agustus 2019, pukul 14.00 WIB, di Universitas Riau.

${ }^{33}$ Herbasuki,Identifikasi Kondisi Dan Upaya Penguatan pengawasan Dalam Rangka Reformasi Birokrasi Di Kabupaten Pekalongan, Jurnal Manajemen Dan Kebijakan Publik, Vol. 1, No.1 , 2015, h. 35. 
lebih terhadap pemakaian alat keselamatan kerja, menyediakan alat keselamatan kerja, dan suatu program kesehatan untuk meningkatkan daya tahan tubuh. ${ }^{34}$

Upaya perlindungan hukum terhadap keselamatan kerja petugas kebersihan tersebut, peneliti mencermati perlu juga upaya lain berupa sosialisasi tentang pentingnya pemakaian alat keselamatan kerja. Keselamatan kerja penting disebabkan dua hal; Pertama, manajemen bertanggung jawab terhadap keselamatan petugas kebersihan. Kedua, rendahnya tingkat kesadaran petugas kebersihan untuk memakai alat keselamatan kerja. Dinas Kebersihan dan Pertamanan harus melakukan sosialisasi mengenai manfaat pemakaian alat keselamatan kerja sebagai upaya preventif dan promotif untuk meminimalkan risiko penularan penyakit kulit pada diri petugas kebersihan. ${ }^{35}$

Penting adanya pemikiran setiap pekerja terlindungi keselamatannya dalam melakukan pekerjaan sehari-hari. ${ }^{36}$ Keselamatan kerja menunjukkan suatu keadaan yang aman dari penderitaan, kerusakan atau kerugian ditempat kerja. ${ }^{37}$ Keselamatan kerja adalah keselamatan yang berkaitan dengan peralatan, tempat kerja dan lingkungan, serta cara-cara melakukan pekerjaan. ${ }^{38}$ Upaya pemakaian alat pelindung diri menempati tingkat pencegahan terakhir dalam hirarki pengendalian, akan tetapi sangat dianjurkan penerapan alat pelindung diri ini. ${ }^{39}$ Sepatutnya petugas kebersihan senantiasa memakai alat keselamatan kerja sebagai alat pelindung diri agar dirinya terlindungi dari risiko bahaya kerja. ${ }^{40}$

\section{KESIMPULAN}

Perlindungan hukum terhadap keselamatan kerja petugas kebersihan Kota Pekanbaru belum sepenuhnya terlaksana disebabkan Dinas Kebersihan dan Pertamanan Kota Pekanbaru belum secara lengkap memberikan alat keselamatan kerja kepada petugas kebersihan, petugas kebersihan sampah seringkali mencari alasan untuk tidak memakai alat keselamatan kerja, dan instansi terkait belum melakukan fungsi pengawasan untuk memonitor petugas kebersihan yang tidak memakai alat keselamatan kerja. Kendala perlindungan hukum terhadap keselamatan kerja petugas kebersihan petugas kebersihan Kota Pekanbaru

${ }^{34}$ Syariah Yeti Fakhrina dan Asniar, Keselamatan dan Kesehatan Kerja, h. 7.

${ }^{35}$ Ni Putu Rusmini, Perilaku Penggunaan Alat Pelindung Diri dan Penularan Penyakit Kulit Pada Petugas TPS di Kecamatan Sawahan, Adi Husada Nursing Journal, Vol. 1, No. 2, Desember 2015, h. 40.

${ }^{36}$ Sri Maulidiah, Perlindungan Pemerintah Terhadap Tenaga Kerja Wanita Di Kota Pekanbaru, Jurnal Kajian Pemerintahan, Universitas Islam Riau, Vol. 3, No. 2, 2004, h. 6.

${ }^{37}$ Anwar Prabu Mangkunegara, Manajemen Sumber Daya Manusia Perusahaan, (Bandung: Remaja Rosdakarya, 2009), h. 161.

${ }^{38}$ Agung Prakasa Supriyatman, Tinjauan Pelaksanaan Keselamatan Kerja dan Kesehatan Kerja (K3) Pada Pekerja Pre Deleivery (PDC) PT. Hadji Kalla, Jurnal Tommalebbi, Vol. IV, No. 2, Juni 2017, h. 155.

${ }^{39}$ Iqlima Intan Yulita, Baju Widjasena, dan Siswi Jayanti, Faktor Yang Berhubungan Dengan Disiplin Penggunaan Alat Pelindung Diri Pada Penyapu Jalan Di Kota Semarang, Jurnal Kesehatan Masyarakat, Vol. 7, No. 1, Januari 2019, h. 331.

${ }^{40}$ Dino Rimantho, Identifikasi Risiko Kesehatan Dan Keselamatan Kerja Pada Pekerja Pengepul Sampah Manual Di Jakarta Selatan, Jurnal Optimasi Sistem Industri, Vol. 14, No. 1, 2015, h. 2. 
disebabkan alat keselamatan kerja diberikan kepada petugas kebersihan tidak sesuai dengan kebutuhan kerja, ketidakpatuhan petugas kebersihan terhadap peraturan yang berlaku, ketiadaan sanksi terhadap petugas kebersihan lalai memakai alat keselamatan kerja, dan instansi terkait belum melakukan fungsi pengawasan terhadap petugas kebersihan.

Dinas Kebersihan dan Pertamanan Kota Pekanbaru harus menyediakan secara lengkap alat keselamatan kerja kepada petugas kebersihan, para mandor harus terus mengingatkan bawahannya untuk memakai alat keselamatan kerja, instansi terkait harus mengawasi petugas kebersihan, mensosialisasikan bahaya tidak memakai alat keselamatan kerja, dan memberikan sanksi terhadap petugas kebersihan yang tidak memakai alat keselamatan. Disarankan kepada Pemerintah Kota Pekanbaru dan DPRD Kota Pekanbaru agar membuat kesepakatan menganggarkan dana setiap tahun untuk pengadaan alat keselamatan kerja. Selain itu, perlu perubahan atas Peraturan Daerah Kota Pekanbaru nomor 8 Tahun 2014 tentang Pengelolaan Sampah yang berisi adanya sanksi terhadap petugas kebersihan sampah yang tidak memakai alat keselamatan kerja.

\section{Daftar Pustaka}

Adnani, Hariza. 2010. Perilaku Petugas Pengumpul Sampah Untuk Melindungi Dirinya Dari Penyakit Bawaan Sampah di Wilayah Patang Puluhan Yogyakarta Tahun 2009, Jurnal KESMAS, Vol. 4, No. 3.

Agustina, Norsita Dkk. 2017. Hubungan Karakteristik Petugas Kebersihan Dengan

Pengelolaan Sampah Di Puskesmas Kota Banjar Baru, Jurnal Publikasi Kesehatan Masyarakat Indonesia, Vol. 4, No. 2.

Dwi Putri, Rahma dan Theozard Fikri, Harry. 2019. Hubungan Antara Lingkungan Kerja Fisik Dengan Kesehatan dan Keselamatan Kerja pada Pasukan Kuning dii Kota Padang, Jurnal PSYCHE 165, Vol. 12, No. 2.

Herbasuki. 2015.Identifikasi Kondisi Dan Upaya Penguatan pengawasan Dalam

Rangka Reformasi Birokrasi Di Kabupaten Pekalongan, Jurnal Manajemen Dan Kebijakan Publik, Vol. 1, No.1.

Intan Yulita, Iqlima, Baju Widjasena, dan Siswi Jayant. 2019. Faktor Yang Berhubungan Dengan Disiplin Penggunaan Alat Pelindung Diri Pada Penyapu Jalan Di Kota Semarang, Jurnal Kesehatan Masyarakat, Vol. 7, No. 1, Januari .

Irzal. 2016. Dasar-dasar Kesehatan dan Keselamatan Kerja. Jakarta: Kencana.

Liswanti,Yane, Ardini S Raksanagara, Sri Yunita. 2015. Faktor-faktor Yang Berhubungan Dengan Kepatuhan Penggunaan Alat Pelindung Diri (ADP) Serta 
Kaitannya Terhadap Status Kesehatan Pada Petugas Pengumpul Sampah Rumah Tangga Di Kota Tasikmalaya Tahun 2014, Jurnal Kesehatan Bakti Tunas Husada, Vol. 13, No.1.

Maharani, Dwi. 2018. Manajemen Komunikasi pada Petugas Kebersihan Kota Palembang, Jurnal Komunikasi, Vol 11, No. 1, Juni.

Masnidar dan Mahyuzar. 2016. Strategi Komunikasi Dinas Lingkungan Hidup, Kebersihan Dan Keindahan Kota Banda Aceh Dalam Menyebarkan Informasi Penanggulangan Sampah Pada Masyarakat Kota Banda, Jurnal ilmiah mahasiswa FISIP Unsyiah, Vol. 3, No. 3.

Maulidiah, Sri. 2004. Perlindungan Pemerintah Terhadap Tenaga Kerja Wanita Di Kota Pekanbaru, Jurnal Kajian Pemerintahan, Universitas Islam Riau, Vol. 3, No. 2.

Monice dan Perinov. 2016. Analisis Potensi Sampah Sebagai Bahan Baku Pembangkit Listrik Tenaga Sampah (PLTS) Di Pekanbaru, Jurnal SainETIn Universitas LancangKuning, Vol. 1, No. 1.

Prabu Mangkunegara, Anwar. 2009. Manajemen Sumber Daya Manusia Perusahaan, Bandung: Remaja Rosdakarya.

Prakasa Supriyatman, Agung. 2017. Tinjauan Pelaksanaan Keselamatan Kerja dan Kesehatan Kerja (K3) Pada Pekerja Pre Deleivery (PDC) PT. Hadji Kalla, Jurnal Tommalebbi, Vol. IV, No. 2, Juni.

Rimantho, Dino. 2015. Identifikasi Risiko Kesehatan Dan Keselamatan Kerja Pada Pekerja Pengepul Sampah Manual Di Jakarta Selatan, Jurnal Optimasi Sistem Industri, Vol. 14, No. 1.

Rudyarti,Edwina. 2017. Hubungan Pengetahuan Keselamatan dan Kesehatan kerja dan Sikap penggunaan Alat Pelindung Diridengan Kejadian Kecelakaan Kerja pada Pengrajin Pisau Batik Di PT.X, Prosiding Seminar Nasional Hasil-Hasil Penelitian Dan Pengabdian Bidang K3.

Rusmini, Ni Putu. 2015. Perilaku Penggunaan Alat Pelindung Diri dan Penularan Penyakit Kulit Pada Petugas TPS di Kecamatan Sawahan, Adi Husada Nursing Journal, Vol. 1, No. 2, Desember.

Saputra, Dody. 2012. Analisis Hubungan Keselamatan dan Kesehatan Kerja (K3) Terhadap Kepuasan Kerja Karyawan Di PT Dystar Colours Indonesia, Skripsi, Program Sarjana Fakultas Ekonomi Dan Manajemen Institut Pertanian Bogor.

Soekanto, Soerjono. 2008. Pengantar Penelitian Hukum. Jakarta:UI Press.

Sundariana, Gea. 2015. Pengawasan Petugas Operasional Kebersihan Kota Pekanbaru (Studi Kasus KeselamatanTenaga Kerja di Kecamatan Tampan), Jom FISIP Universitas Riau, Vol. 2, No. 2.

Yeti Fakhrina, Syariah dan Asniar. 2017. Keselamatan dan Kesehatan Kerja Pada Petugas Kebersihan Di Kota Banda Aceh, Jurnal Ilmiah Mahasiswa Fakultas Keperawatan, Vol. 2, No. 3. 